\title{
Perspectives on the use of lakes and ponds as model systems for macroecological research
}

\author{
Joaquín HORTAL, ${ }^{1,2,3^{*}}$ João C. NABOUT, ${ }^{4}$ Joaquín CALATAYUD, ${ }^{1,5}$ Fernanda M. CARNEIRO, ${ }^{6}$ André PADIAL, \\ Ana M.C. SANTOS, ${ }^{1,2}$ Tadeu SIQUEIRA, ${ }^{8}$ Folmer BOKMA, ${ }^{9}$ L. Mauricio BINI, ${ }^{3}$ Marc VENTURA ${ }^{10,11}$
}

\begin{abstract}
${ }^{1}$ Departamento de Biogeografía y Cambio Global, Museo Nacional de Ciencias Naturales (MNCN-CSIC), C/José Gutiérrez Abascal 2, 28006 Madrid, Spain; ${ }^{2}$ Centro de Biologia Ambiental and Portuguese Platform for Enhancing Ecological Research \& Sustainability, Faculdade de Ciências da Universidade de Lisboa (CBA-FCUL-PEERS), Edifício C2, Campo Grande, 1749-016 Lisboa, Portugal; ${ }^{3}$ Departamento de Ecologia, Universidade Federal de Goiás, 74001-970 Goiânia, GO, Brazil; ${ }^{4}$ Unidade de Ciências Exatas e Tecnológicas, Universidade Estadual de Goiás, Br-153, 75132-903, Anápolis, Brazil; ${ }^{5}$ Departamento de Ciencias de la Vida, Universidad de Alcalá, Edificio de Ciencias, Ctra. Madrid-Barcelona km. 33,6, 28871 Alcalá de Henares, Madrid, Spain; ${ }^{6}$ Núcleo de Educação Ambiental e Pesquisa em Biologia - NEAP-Bio, Universidade Estadual de Goiás (UEG), Unidade Universitária de Iporá (UnU-Iporá), Bairro jardim Novo Horizonte 2, Iporá, GO, Brazil; ${ }^{7}$ Departamento de Botânica, Universidade Federal do Paraná, Av. Coronel Francisco H. dos Santos, 81531-990, Curitiba, PR, Brazil; ${ }^{8}$ Instituto de Biociências, UNESP - Universidade Estadual Paulista, Departamento de Ecologia, Rio Claro, Brazil; ${ }^{9}$ IceLab and Department of Ecology and Environmental Science, Umeå University, S-90187 Umeå, Sweden; ${ }^{10}$ Center for Advanced Studies of Blanes, Spanish Research Council (CEAB-CSIC), Biodiversity and Biogeodynamics Group, Blanes 17300 , Girona, Catalonia, Spain; ${ }^{11}$ Institut de Recerca de l'Aigua, Universitat de Barcelona, Av. Diagonal 684, 08034 Barcelona, Catalonia, Spain *Corresponding author: jhortal@mncn.csic.es
\end{abstract}

\begin{abstract}
Macroecology studies large-scale patterns aiming to identify the effects of general ecological processes. Although lakes (and ponds) are particularly suited for macroecological research due to their discrete nature and non geographically-structured variability, the development of this discipline in lentic habitats is comparatively much smaller than for terrestrial environments. This is despite the interest of limnologists for large-scale phenomena, which results in the high level of development of some disciplines such as predictive limnology. Here we discuss how current state-of-the-art in macroecology may benefit from research in lentic habitats at five topics. First, by including an island biogeography analytical framework to incorporate the effects of lake origin and history on lentic biodiversity. Second, by studying local and regional effects on the latitudinal gradients of species richness. Third, by considering lakes and ponds altogether for the study of beta diversity and metacommunity structure, which is already common ground in limnological research. Fourth, by relating species traits with ecosystem structure and functioning; here we consider in particular the potential effects of body size-determined dispersal and competitive exclusion processes on lake-wide trophic organization. And fifth, by incorporating current research in functional (i.e., trait) and phylogenetic diversity to the study of community structure. We finally conclude that lentic habitats can be particularly important for the development of the most functional aspects of macroecology, due to the relative ease of studying the different biotic and abiotic components of the system separately, compared to most terrestrial systems. This can allow teasing apart many of the confounding factors that are characteristic of macroecological research, thus helping the development of future theoretical syntheses.
\end{abstract}

Key words: biodiversity gradients, body size, dispersal, ecosystem functioning, ecosystem structure, metacommunity.

Received: October 2013. Accepted: November 2013.

\section{INTRODUCTION}

Macroecology can be defined as large-scale ecology. As such, it aims to study the ecological and evolutionary forces that influence patterns in the abundance, distribution, traits and diversity of species (Brown and Maurer, 1989; Hawkins and Diniz-Filho, 2008). The essence of the macroecological research agenda involves studying ecological systems across spatial (and temporal) scales using a top-down approach, assuming that the unifying principles acting on biodiversity that are not unique to any particular local system will be easier to detect at large spatial (and temporal) scales. This transversal discipline now involves using analyses on data gathered at different spa- tial and temporal scales to study current and past relationships between organisms and their environment (including other organisms), as well as temporal (i.e., macroevolutionary) trends (Hawkins and Diniz-Filho, 2008; Diniz-Filho et al., 2013). Indeed, this discipline seeks processes that are general, unifying, and not specific to any particular system or location. This view is allowing us, for instance, to obtain a deeper understanding of current gradients in the diversity of species (Hortal et al., 2011; Gouveia et al., 2013), ecological traits (Diniz-Filho et al., 2009) and species' distributions (Olalla-Tárraga et al., 2011; Gouveia et al., 2014). The imprint of macroecology (and macroevolution) on modern ecology is so 
large that it recently led to Ricklefs' (2008) proposal of disintegrating the concept of local ecological community and favouring instead a more regional perspective on the effects and evolution of biotic interactions and environmental adaptations.

To date, macroecological studies have predominantly concerned terrestrial systems, and the organisms and communities inhabiting water bodies have been less studied from this particular macroecological perspective. However, it would be inaccurate to say that aquatic ecologists were blind to macroecological questions in the past. If we assume that a fundamental component of the macroecological research program roughly consists in analyzing a large number of ecological particles (sensu Brown and Maurer, 1989) over broad spatial and temporal scales in the search for patterns and explanations, then a number of examples can be cited. For instance, within a field known as predictive limnology ${ }^{1}$ (Håkanson and Peters, 1995), a number of studies used data from dozens of lakes to predict aggregate community variables (e.g., the biomass and cover of aquatic macrophytes) in function of environmental predictors (e.g., lake size, underwater light and lake slope; Chambers and Kalff, 1985; Duarte et al., 1986). More recently, the large collaborative project FADA (Freshwater Animal Diversity Assessment) compiled and described current knowledge on the worldwide coarse-grain distribution of animals and macrophytes from aquatic continental ecosystems (Balian et al., 2008), providing the baseline knowledge for large-scale studies on c. 60 different taxa. Other recent examples include the study of large-scale biodiversity gradients (Griffiths, 2006; Hof et al., 2008; Stomp et al., 2011; Stendera et al., 2012; Brucet et al., 2013; Azevedo et al., 2013; Griffiths et al., 2014), or the conjecture that ponds and small lakes have a disproportionate importance for global biogeochemistry cycles (Downing, 2010). These and many other examples illustrate that the macroecological perspective has been an integral part of the study of inland waters, despite lentic habitats being somehow out of the macroecological research agenda. Importantly, data used in the studies cited above (both for the response variables, as species richness, or, for predictor variables, as nutrients) were mainly obtained in the field with comparable methods, instead of being compiled from atlases or from the use of remote sensing techniques. Therefore, they benefit from comprehensive, fine-grained datasets covering large spatial extents, a rare (and desirable) combination in macroecological studies (Beck et al., 2012).

Given the above, the relative paucity of macroecologi- cal studies on lake ecosystems when compared to terrestrial ecosystems is surprising and unfortunate. It is surprising because one of the earliest studies in macroecology was conducted on lakes (Barbour and Brown, 1974). It is unfortunate because lakes have some unique features (explained in detail below) that allow teasing apart hypotheses that typically cannot be evaluated using terrestrial systems. Studies on the biodiversity of lakes and other water bodies (herein lakes for short) have traditionally focused on local scales (i.e., within a lake), paying particular attention to local dynamics, such as mixing regimes, trophic networks or local spatial gradients (e.g., horizontal gradients in reservoirs). It was also through these local studies that the relationships of the biological component with environmental variables started to be understood (i.e., the lake as a microcosm; Forbes, 1887; see the discussion in this issue by Jenkins, 2014), providing the roots of most modern ecological knowledge (Hutchinson, 1957; Odum, 1963; Margalef, 1984; see Colwell and Rangel, 2009). However, in many regions aquatic ecologists started to sample over large spatial extents only recently. For example, most studies on phytoplankton in Brazil are still local; while almost two thirds of the articles published by Brazilian limnologists are local, the proportion of works conducted at the regional scale is increasing (Nabout et al., 2009, 2013; Wetzel et al., 2012). A result of this traditional focus on the local scale is the paucity of macroecological knowledge on lakes; a restrictive search on Scopus ${ }^{2}$ rendered only 13 studies of macroecology on lakes, and 39 additional works studied biogeographical gradients on lakes ${ }^{3}$. A thorough revision looking for evaluations of hypotheses about biodiversity gradients in freshwater habitats found a total of only 87 relevant studies for lakes (Stendera et al., 2012).

Despite the lack of macroecological studies conducted so far, lakes are particularly suited for macroecological research. This discipline typically aims to characterize phenomena across large numbers of comparable ecological particles, and in fact very few ecosystems are so well delimited (in relative terms) as lakes, which constitute islands within an unsuitable matrix with relatively easy-tomeasure characteristics. lakes of various ages, sizes and physical, chemical and biological characteristics can be found at different climates (Margalef, 1983; Lewis, 1996; Wetzel, 2001; Elser et al., 2010). Further, the correlation between lake temperature and productivity is, in general, not strong (Lewis, 2000). All these characteristics make lakes particularly suitable to disentangle the effects of different concurring factors that are often more correlated in terrestrial ecosystems. Nonetheless, the particular charac-

\footnotetext{
1 A body of research that uses theories in limnology to describe, manipulate and control the environment (Peters, 1986).

2 Search at http://www.scopus.com/ on 01/10/2013, using the terms TITLE-ABS-KEY(lake* macroecol*).

3 Search at http://www.scopus.com/ on 01/10/2013, using the terms TITLE-ABS-KEY(lake* biogeogr* gradient*).
} 
teristics of lake biotas add an interesting dimension to macroecological studies. Apart from the distribution into trophic levels that is common to all ecosystems, lake biotas are segregated between spatially distinct habitats: the limnetic zone - the portion of the water body open to the photosynthetically active radiation penetration; benthos the deepest part of the lake, normally the surface of the sediment; and littoral - the shallowest part of the lake shore. Two interacting communities are traditionally distinguished in the limnetic zone for operational reasons, the nekton (active swimmers) and the plankton (organisms suspended in the water column) (Lampert and Sommer, 2007). Depending on lake depth and transparency light can reach the sediment. In this case, both the littoral and benthos have a rich primary producer community; otherwise such communities are restricted to the littoral. This spatial and depth stratification effectively creates different ecological systems that will show differential responses to the same factors and stressors.

Importantly, the size of lentic habitats influences the levels of physical, chemical and biological interactions between limnetic and littoral zones, thereby determining the whole ecological dynamics of the lake. Water bodies with more than two hectares in area are generally considered lakes, while smaller ones are considered ponds (Biggs et al., 2005). From a macroecological perspective lakes and ponds are discrete ecological particles that share the same spatial matrix. Further, although ponds are more numerous and smaller in size, most species have different discrete populations in each of them. While both lakes and ponds have traditionally been used for metapopulation and metacommunity studies (Jenkins and Buikema Jr., 1998; Cottenie et al., 2003; Leibold and Norberg, 2004; Heino and Soininen, 2010; Logue et al., 2011), lakes have been comparatively more studied from a biogeographical perspective (Verleyen et al., 2009; Poquet and MesquitaJoanes, 2011). However, the different ecological and biogeographical processes affecting species distributions and community diversity interact across scales in a hierarchically structured way (Rajaniemi et al., 2006; Hortal et al., 2010, 2012; Guisan and Rahbek, 2011). For example, lake communities may be more controlled by deterministic processes at larger spatial scales, while pond communities may be more influenced by stochastic factors at ecological time scales, as many ponds experience cyclic periods of drought (Chase, 2007). These scale-related changes can alter the concordance between the freshwater biotas of several groups (Paavola et al., 2006). We thus believe that research on lentic communities from a macroecological perspective will benefit from considering the size-scaling between ponds and lakes explicitly in the analyses, at least for organisms inhabiting both types of habitats.

Here we examine how five major macroecological questions, namely island biogeography, geographical gra- dients of biodiversity, metacommunities, species' trait variations and community structure, can be, and have been, investigated in lakes. We make it under the assumption that the observed patterns, and the process behind them, may change from the terrestrial to the lentic systems. If that is the case, current macroecological knowledge will be advanced. When, on the contrary, patterns and/or processes are similar, these studies will add support to the generality of particular aspects of current macroecological theory. Although the results of macroecological research can inform applied fields such as conservation management through the disciplines of systematic conservation planning (Margules and Pressey, 2000) and conservation biogeography (Whittaker et al., 2005), we have deliberately excluded this aspect from the questions we discuss. We do this because a proper description of the state-of-the-art and its application to lentic habitats (such as in e.g., Nel et al., 2009) would require a detailed discussion that is certainly out of the eminently theoretical aim of our text. In sum, our aim is to provide a perspective rather than a comprehensive review, considering the benefits -and some caveats- of using lentic habitats as study systems for macroecological research, and highlighting several potential future lines of research. We will focus primarily on lakes, but we note that most (if not all) of the research questions we review can also be applied to ponds (see Boukal, 2014; De Meester and Pantel, 2014; Jenkins, 2014; Gravel et al., 2014).

\section{Lakes as islands within terrestrial seas}

Researchers have long been interested in islands. Their isolate and discrete nature makes them the perfect natural experiments to study evolutionary and ecological patterns. Islands have in fact served as the foundations of several basic theories in different research topics (MacArthur and Wilson, 1963; 1967; Diamond, 1969, 1970; MacArthur et al., 1972; Emerson, 2002; Gillespie and Roderick, 2002; Ricklefs and Bermingham, 2008; Whittaker et al., 2008). The Theory of Island Biogeography (MacArthur and Wilson, 1963, 1967) is one of the most influential theories in modern ecology (Losos and Ricklefs, 2009). MacArthur and Wilson proposed that the number of species on an island tends to an equilibrium state resulting from the balance between immigration and extinction rates. Their model implies that the fundamental processes of dispersal and colonization should vary in a predictable way in relation to isolation and area. Immigration rate should decline with increasing isolation, and extinction rate should decline with increasing area (a general surrogate for the total carrying capacity of the island). Although many other factors can shape island diversity (e.g., habitat diversity: Hortal et al., 2009; island age: Whittaker et al., 2008; species pool diversity: Santos et al., 2011), the Theory of Island Biogeography is still one of the most empirically supported theories in ecology. 
Islands have different sizes, shapes, geology, environments, and history, which make each one of them unique entities (Whittaker and Fernández-Palacios, 2007). One can think of islands not simply as pieces of land surrounded by water (i.e., true islands), but also as a suitable habitat surrounded by a matrix of unsuitable habitats (Whittaker and Fernández-Palacios, 2007). Although lakes are not completely isolated from the terrestrial systems, they are easy to define spatially and present a clearly distinct biota from that of the surrounding systems. Therefore, lakes can also be perceived as islands within a sea of terrestrial landscapes (Keddy, 1976; Eadie et al., 1986; Minns, 1989; Heino, 2011), having also its own size, shape, diversity and history, as any other true island. Although lakes could serve as good models to study island biogeography theory, relatively few works have done so (but see e.g., Hubbard, 1973; Browne, 1981; Hockin, 1982; Brönmark, 1985; March and Bass, 1995; Harris et al., 2011; Brooks and Colburn, 2012). Most of the tests of island biogeography theory in lakes focus on the relationship between species richness and lake surface area and/or isolation (March and Bass, 1995; Rolon et al., 2008; Bagella et al., 2010; Bosiacka and Pieńkowski, 2011; Brooks and Colburn, 2012). But when variables such as water quality (Rørslett, 1991) or lake history (e.g., Minns, 1989; Lévêque et al., 2008) are taken into account, they do show significant explanatory power. It is likely that research traditions are responsible for the study of variation in lacustrine species richness over large spatial scales being modelled by a different set of predictors in addition to lake area. Current theory of island ecology and biogeography introduces many aspects that could be directly applied to the study of lake diversity, particularly the influence of age, habitat diversity (Rolon et al., 2008) or lake depth, that can be to some extent analogous to elevation on islands.

\section{Geographical gradients of species richness}

The decrease in species numbers from the equator to the poles is one of the most striking and best known patterns in nature (Hawkins, 2001), and despite notorious exceptions (see Rabenold, 1987; Kouki et al., 1994; Mori et al., 2010; Santos and Quicke, 2011), it is generally consistent regardless the geographic region, scale or taxon (Hillebrand, 2004). To date more than thirty hypotheses have been proposed to explain this pattern (see Willig et al., 2003; and Hawkins, 2008 for a review), and according to Mittelbach et al. (2007) they can be grouped into three main types: i) ecological hypotheses focused on the maintenance of diversity, mainly due to higher energy input (or productivity) (Weyhenmeyer et al., 2013); ii) historical hypotheses which sustain that the extent and duration of tropical climate on the Earth's history allowed longer time for the species to diversify and accumulate (Hawkins et al., 2007); and iii) evolutionary hypotheses which propose higher diversification rates in the tropics (Allen and Gillooly, 2006).
Grouped within the historical hypotheses, the effect of Pleistocene glaciations on current richness gradients deserves an especial mention. Firstly, because it has been traditionally neglected (Francis and Currie, 2003) and secondly because of the increasing body of evidence documenting their effects on many groups (Svenning and Skov, 2007; Hortal et al., 2011; Griffiths et al., 2014). Lentic faunas are not an exception to this. Glacial waters host less diverse biotas (Gesierich and Rott, 2012), which would have caused massive extinctions in the glaciated areas. Hence, most temperate lakes host particularly species-poor fish communities due to limitations to post-glacial recolonisation and low diversification rates in cold waters (Minns, 1989; Amarasinghe and Welcomme, 2002). Although ecological explanations of the latitudinal gradient have been preponderant, during the last decade, historical and evolutionary explanations have gained relevance and some authors have gone further proposing them as the principal forces driving this pattern (Wiens and Donoghue, 2004; Hawkins, 2008). Yet, despite some attempts at reconciliation (Hortal et al., 2011), the debate is still open.

One of the reasons for the lack of consensus comes from the fact that most studies exploring latitudinal gradients have been conducted over large landmasses, where potential explanatory factors are correlated and may interact synergistically (Willig et al., 2003). In that sense, lakes constitute an excellent study system to evaluate the hypothesized mechanisms underpinning latitudinal richness gradients. On the one hand, most - if not all - freshwater organisms show latitudinal diversity patterns (see Collen et al., 2013), although the generality and strength of these gradients in microscopic organisms is under debate (see contrasting views at Finlay et al., 1996; Finlay and Esteban, 2007 and Heino et al., 2011 compared with Vyverman et al., 2007; Fontaneto and Brodie, 2011; Hortal, 2011; Fontaneto and Hortal, 2012, 2013). On the other hand, despite some general environmental influences, lake characteristics (such as area, age, temperature or productivity) are not necessarily correlated, or at least are not as spatially autocorrelated as the characteristics of terrestrial landscapes. These characteristics make direct hypothesis testing easier in lentic habitats, even though several factors can interact to affect diversity gradients in a non-linear way (see Matuszek and Beggs, 1988).

Despite their potential, few studies have explored the strength and potential mechanisms underlying the geographical diversity gradients in lakes. However, the ones that do so show offer valuable insights on the general characteristics of the geographic variations in diversity (see Barbour and Brown, 1974; Minns, 1989; Gillooly and Dodson, 2000; Amarasinghe and Welcomme, 2002; Lévêque et al., 2008; Verleyen et al., 2009; Stomp et al., 2011; Stendera et al., 2012; Pinel-Alloul et al., 2013). Many variables, related to different ecological processes, can drive geographic gradients in lake species richness. 
Recently, Stomp et al. (2011) found that local environmental variables such as water temperature, chlorophylla, lake area and depth had significant effects on phytoplankton diversity. Further, the availability of solar energy has been found to correlate with the species richness of pelagic crustaceans in a large cold temperate region (1665 Canadian lakes; Pinel-Alloul et al., 2013). And while fish diversity of cold temperate lakes is affected by their glacial history (Minns, 1989), ancient lakes host disproportionally rich fish faunas (Lévêque et al., 2008).

The geographical concordance of diversity patterns in different groups also offers valuable insights. Unsurprisingly, freshwater vertebrates and decapods show distinct global-scale patterns of species richness and threatened and rare species when compared to terrestrial mammals and birds (compare Figure 1 in Grenyer et al., 2006 with Figure 1 in Collen et al., 2013). Further, Griffiths et al. (2014) found differences in the responses of freshwater fish to climate variation between North American and European and between generalist and specialist species, as well as significant effects of historical predictors on the richness of migratory species. However, it is interesting to note that the patterns of decrease in diversity with latitude are similar for phytoplankton (Stomp et al., 2011) and pelagic crustaceans (Pinel-Alloul et al., 2013).

Recent works point to the convergence in the macroecological patterns among different freshwater groups (see Soininen, 2012; Tisseuil et al., 2013). Behind such general convergence, the disagreement among significant environmental variables also highlights the importance of the particular characteristics of each species group and their responses to lake characteristics as determinants of local diversity. This is in agreement to the perspective that no single mechanism is enough to account for the origin of geographical diversity gradients (Hortal et al., 2011). Nonetheless, there is large body of evidence on the determinants of species diversity and community structure in lakes (Amarasinghe and Welcomme, 2002; Fallu et al., 2002; Rosenfield, 2002; Hessen et al., 2006; Lappalainen and Soininen, 2006; Mehner et al., 2007; Muylaert et al., 2010; Olden et al., 2010; Collen et al., 2013; Weyhenmeyer et al., 2013). Despite the multiplicity of hypotheses and groups, formal meta-analyses (or informal ones, such as Stendera et al., 2012) may allow identifying the main general drivers of lake diversity.

Incorporating lakes into the macroecological research agenda can contribute to shed light to a problem that has intrigued scientists during two centuries. Of course, macroecological analyses of lake data is not free of problems. Temporal variations in the composition and diversity of lakes could affect the results of the analyses of diversity gradients, as the distribution and diversity of many groups are shifting with climate changes (Hallstan et al., 2013). In addition, survey unevenness and incompleteness may com- promise data quality (Hortal et al., 2007; Straile et al., 2013). However, additional studies are yet necessary to evaluate the relative importance of large-scale environmental gradients, watershed characteristics, historical factors, and local characteristics for lake diversity. These studies may incorporate large datasets from taxa or species groups of different trophic levels and detailed information on the origin and biogeochemical characteristics of lakes, in order to complement the existing knowledge.

\section{Beta-diversity and metacommunities in lentic habitats}

Given that lakes have discrete borders defining the extent of the aquatic habitat, a set of lakes in a large region is an ideal model to study compositional variation from a metacommunity perspective. That is, the perspective of multiple communities connected by dispersing organisms (Leibold et al., 2004) that are affected by local and regional processes (see Ricklefs, 2008). Given that a major goal of community ecology is to describe and explain how and why the composition of biological communities varies in space and time, ecologists have made great advances recently in understanding beta-diversity - the spatial or temporal variability of species composition (Anderson et al., 2011). Not surprisingly, the increase in the number of articles on metacommunities and beta-diversity in lakes accompanied the overall increase of the number of publications about the topic (Fig. 1; see also

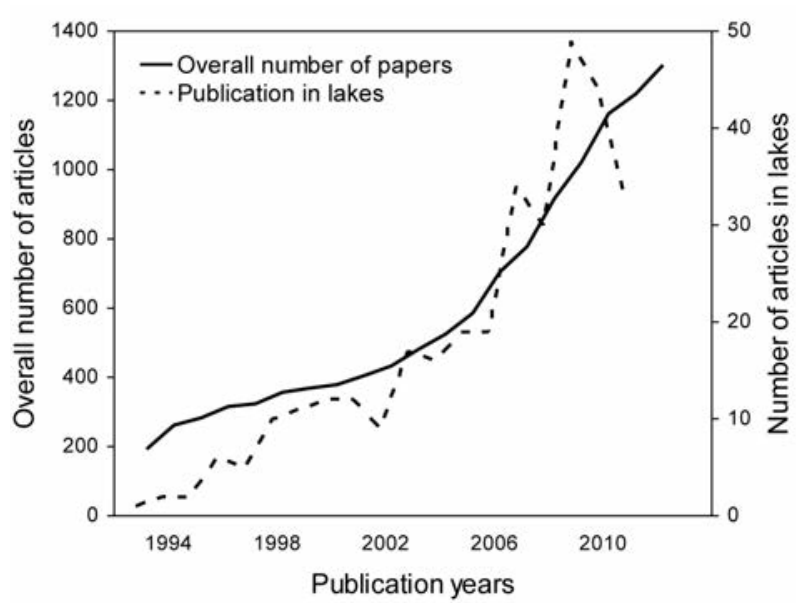

Fig. 1. Number of publications in the last 20 years (1992-2012) indexed in ISI web of science database about metacommunities or beta-diversity per year (left axis, $\mathrm{N}=12,017$ ) and about the same topic only in lakes (right axis, $\mathrm{N}=384$ ). Search conducted at http://www.webofknowledge.com/ on 24/09/2013 using the terms TITLE-ABS-KEY("metacommunit"” OR "beta-diversit*" OR "beta diversit*") for overall number of articles, and TITLE-ABSKEY ("metacommunit*" OR "beta-diversit*" OR "beta diversit*" AND "lake*") for number of articles about lakes. 
Logue et al., 2011). In fact, the study of a set of interconnected ponds made by Cottenie et al. (2003) is one of the first and most influential attempts to confront the relative role of local and regional processes on the spatial variation of zooplankton communities (but see also Warren, 1996). In another study, Beisner et al. (2006) showed that crustacean zooplankton and fish were more constrained by dispersal-based processes than bacteria and phytoplankton in a set of Canadian lakes. These results are in line with Nekola and White's (1999) prediction of steeper distancedecay relationship for organisms with lower dispersal abilities when compared to those organisms with higher dispersal abilities.

lakes are a good model system to investigate the relationship between dispersal ability, landscape structure and metacommunity structure. One can, for example, compare the output of a variation partitioning analysis or the distance-decay relationship between weaker dispersers, such as fish, and stronger dispersers, such as the microbiota (Beisner et al., 2006; Var der Gucht et al., 2007). A deconstructive trait-based approach within each one of these broad categories can be also fruitful (Algarte et al., 2013; Grönroos et al., 2013). This debate has received much attention among macroecologists, given that the relative importance of niche- and dispersal-based processes varies across spatial scales (Hortal et al., 2010). For example, Chase (2010) manipulated productivity in a set of experimental ponds and found that within-pond species richness in low and high productivity treatments were very similar after a 7-year experiment. He found, however, consistently high beta-diversity among high-productivity ponds (i.e., at a within-region scale), in comparison with low-productivity ponds. Chase's study shows that deterministic processes predominate in low productivity ponds, making them very predictable, whereas stochastic processes predominate in high productivity ponds. In contrast, Van der Gucht et al. (2007) highlighted the power of species-sorting mechanisms on lake bacteria over a wide range of spatial scales. These authors demonstrated that bacteria have weak dispersal limitation and that, given their rapid grow rate, species sorting along environmental gradients drives bacteria metacommunity dynamics. However, many other groups present strong dispersal limitations. Therefore, modern bioassessment ${ }^{4}$ approaches must integrate niche, dispersal and biotic interactions (Heino, 2013). Given their discrete nature, lakes may constitute good model systems to determine the effects of landscape structure and complexity on the relative importance of neutral and nichebased processes (see Gravel et al., 2014). These are just a few examples of how studies focusing on lakes can provide theoretical advances of major importance for the understanding of community variations.

\section{Species' traits, body size and ecosystem structure and functioning}

Macroecologists are interested in characterizing how variations in physiological and functional traits represent the effects and evolution of the species' niche, through their relationships with environmental gradients and other species within the community. Studies showing evidences of local adaptation in species traits are abundant in aquatic ecology (see De Meester and Pantel, 2014 for a recent example). There are also studies showing geographical patterns in traits of freshwater organisms (Heino et al., 2013). The strongest effects of environmental gradients have been found on traits related with biotic interactions such as predation (Hairston and Walton, 1986; Cousyn et al., 2001), omnivory (González-Bergonzoni et al., 2012) and parasitism (Ebert, 1994), as well as in traits that can be directly affected by climatic changes such as physiological adaptations to increasing water temperature. Amongst them, temperature-related adaptations have been found to prevent immigration success in zooplankton (Van Doorslaer et al., 2009), to avoid habitat colonisation in fish (Ohlberger et al., 2008), and to foster phenotypic divergence in amphibians (Richter-Boix et al., 2010). Geographic gradients of temperature are also a key factor determining species distributions and affecting traits such as body size (Gillooly and Dodson, 2000). In fact, the ecophysiological constraints occurring at the local scale of a pond or a lake scale up to determine the evolution of the thermal niche of freshwater species, such as anuran tadpoles (Gouveia et al., 2014).

One of the traditional assumptions of ecology is that the ecological role of the species varies according to their differences in a series of traits with functional significance (see Messier et al., 2010). Ecosystem processes are known to depend on the range of species' traits present in each ecosystem (Tilman, 2001). One of the most important traits for understanding large-scale ecological patterns is body size. Alike land organisms, freshwater species show a negative relationship between abundance and body size (Jonsson et al., 2005; YvonDurocher et al., 2011). But most importantly, body size is related to dispersal ability of the species (Gillooly and Dodson, 2000; De Bie et al., 2012), resulting in a wide range of differences in macroecological and biogeographic patterns (Fontaneto and Brodie, 2011; Hortal, 2011; Fontaneto and Hortal, 2012, 2013). At large scales, dispersal ability can sometimes be more important than

\footnotetext{
4 Bioassessment, or biological assessment, is an evaluation of the condition of a waterbody using biological surveys and other direct measurements of the resident biota in surface waters (Barbour et al., 1999).
} 
environmental variables (Heino et al., 2012), although environmental gradients can also produce isolation between water bodies and promote rapid adaptive processes that result in niche differentiation (see De Meester and Pantel, 2014). Body size also determines the ecological role and niche position of aquatic organisms (Maly and Maly, 1974; Chase and Leibold, 2003), particularly for large-sized organisms. In large organisms such as fish, limiting similarity processes can exclude species of similar size from particular lakes, whereas the high dispersal capacity of small-sized organisms may counteract the effect of these processes (Fenchel and Finlay, 2004; but see Hortal, 2011; Fontaneto and Hortal, 2013). Due to this, the distributions of small-sized organisms would be more structured by large-scale geographical gradients and landscapescale spatial processes and the large-sized organisms by within-lake niche-related processes (Martiny et al., 2006; Soininen et al. 2011; see however De Meester et al., 2002; De Bie et al., 2012). Following the framework proposed by Hortal et al. (2010) the relative importance of scenopoetic ${ }^{5}$, biogeographic and occupancy dynamics factors will be higher for microorganisms, whereas bionomic $^{6}$ factors will be most important for aquatic vertebrates inhabiting lentic habitats.

Here we argue that the effects of body size on biogeographic patterns (sensu Fontaneto and Brodie, 2011) may affect the ecological functions performed by guilds of organisms with different sizes. Trait diversity show a positive relationship between ecosystem functioning and resilience (Hooper et al., 2005; Scherber et al., 2010). Therefore, if large-sized organisms show less trait variability within a single lake than small-sized ones due to increasing strength of limiting similarity processes (see above), then the ecological functions performed by progressively smaller species groups will be enhanced and more resistant to environmentally-induced changes in lakes and other water bodies. As the major ecological guilds inhabiting lentic systems are also body size-structured, the differences in the biogeographic characteristics of macroscopic and microscopic organisms may have a significant effect in the trophic structure of lakes placed in different parts of the world. The reliance on body size as a major structuring factor does not mean that the incorporation of other traits would not be necessary to attain a better knowledge on aquatic food webs (Boukal, 2014). Also, the high density of large organisms in the higher trophic levels leads to deviations from the typically triangular trophic pyramids. Particularly, a more asymmetric or even inverted pattern across trophic levels may occur (Jones and Jeppesen, 2007).

The introduction of predators such as fish is amongst the most important factors affecting community composition in lakes (Knapp et al., 2001). Freshwater fish are one of the animal groups with higher number of invasive species (Hulme et al., 2009). The weak resistance of lacustrine habitats to fish invaders (Irz et al., 2004) results in within-lake alterations in trophic relationships and substantial effects on lake biodiversity (Vitule et al., 2009). Since their impact is widespread and relatively well documented, the changes in trophic relationships in lakes associated with invasive species offer new opportunities to study the effects of trophic changes in different biogeographic regions (Brose et al., 2004). If, as we hypothesize, the ecological performance of large species can be highly variable, global change effects such as the appearance of invasive species could produce large differences in the trophic structure of lakes located in the same climatic domains, breaking down the more consistent functioning of the lower trophic levels. Several studies on the impact of invasive fish and crustaceans provide evidence for disruptions of the ecological dynamics of lakes (Feroz Khan and Panikkar, 2009; Wahl et al., 2011; Cucherousset et al., 2012; Strock et al., 2013), while others do not (Nilsson et al., 2012; Jackson et al., 2013). These mixed (though not necessarily contradictory) results may be due, among other things, to the wide variety of approaches used, or the influence of other global change stressors. For example, warming can cause changes on phytoplankton size that are uncoupled with changes in zooplankton, thus resulting in a reorganization of the biomass structure of the food web (YvonDurocher et al., 2011) and generating strong changes in ecosystem functioning. Thus, further studies conducted in a standardized way are needed (Cucherousset and Olden, 2011). Although hypotheses similar to ours have been formulated recently (see Blanchet, 2012; Dick et al., 2013), as far as we know they have not been formally evaluated to date. It thus seems worth investigating further their validity and the generality.

\section{Functional and phylogenetic community structure}

Community structure has been traditionally described using species richness. However, such approach presents

\footnotetext{
5 According to Hutchinson (1978), the environmental conditions that set up the scene for the basal growth rate of populations, for which competition is not relevant; they are commonly referred to simply as conditions in niche theory (see Soberón, 2007).

6 Also following Hutchinson's (1978) terminology, all factors related with species interactions and consumption of resources, either affecting competition and/or the impacts that consumers have on the resources (Chase and Leibold, 2003); they are commonly referred to as resources in niche theory (see Soberón, 2007).
} 
important limitations, since it assumes that all species contribute equally to biodiversity (Magurran, 2004). As a result, the last 20 years have seen an increasing interest in studying other aspects of community structure, namely through the use of functional and/or phylogenetic diversity (Fig. 2). According to Tilman (2001), functional diversity describes the value and range of variation of the traits shown by the species present in the ecosystem, that influence ecosystem functioning. So, according to this definition, functional diversity links individuals with their traits (Violle et al., 2007) and the functions they perform
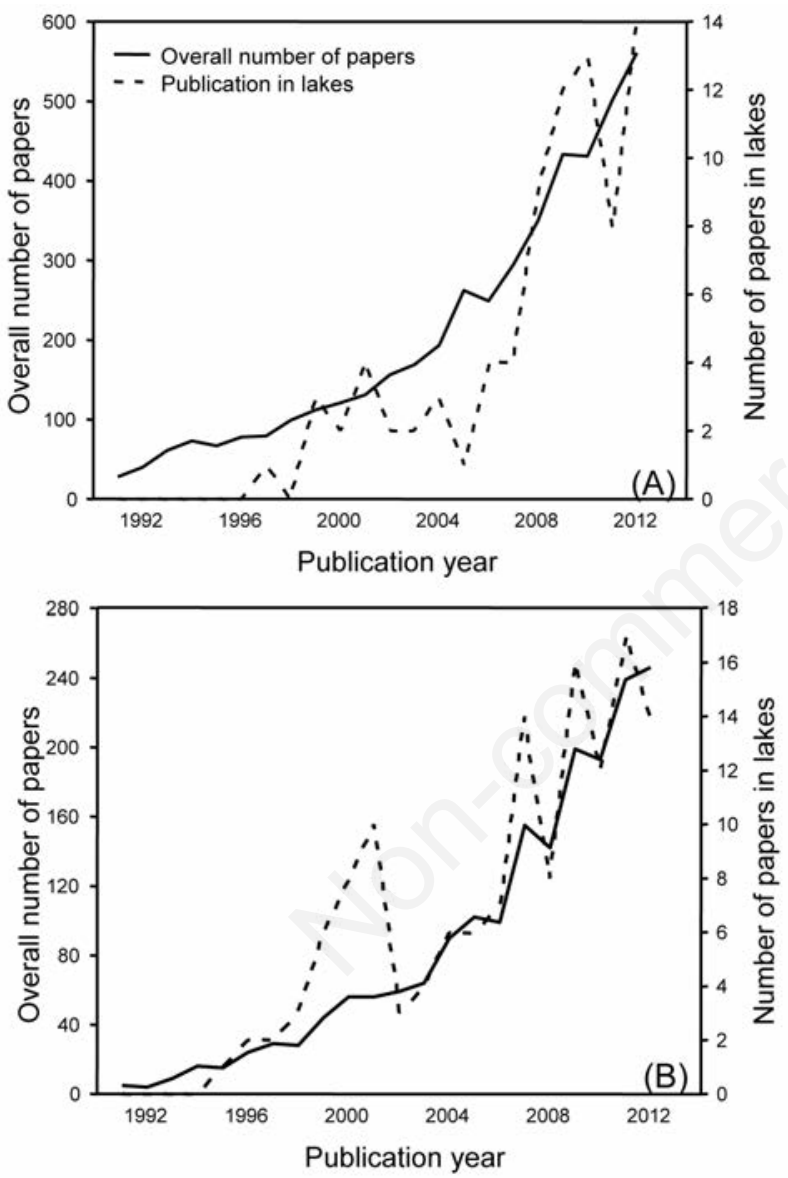

Fig. 2. Number of publications in the last 20 years (1992-2012) indexed in ISI web of science database about: A) functional diversity per year (left axis, $\mathrm{N}=4908$ ) and about the same topic only in lakes (right axis, $\mathrm{N}=92$ ). B) phylogenetic diversity per year (left axis, $\mathrm{N}=2074$ ) and about the same topic only in lakes (right axis, $\mathrm{N}=155$ ). Search conducted at http://www.webofknowledge.com/ on 24/09/2013 using the terms TITLE-ABS-KEY("functional diversit*") for overall number of articles; TITLE-ABS-KEY("functional diversit*" AND lake*) for number of articles in lakes; TITLE-ABS-KEY ("phylogenetic* diversit*") for overall number of articles; and TITLE-ABS-KEY ("phylogenetic* diversit*" AND lake*) for the number of articles in lakes. in the ecosystems. Another way of assessing the patterns of community assembly and structure is through phylogenetic diversity, which measures the phylogenetic relationships between the species inhabiting the community (Magurran, 2004). Here, diversity will be higher in communities where species are phylogenetically most distinct. There are several methods for estimating functional and phylogenetic diversity (see Faith, 1992; Webb, 2000; Pausas and Verdú, 2010; Pavoine and Bonsall, 2011; Vamosi, 2014), each one of them conveying distinct facets of diversity.

Both functional and phylogenetic diversity can be used to ascertain the processes determining community assembly (Díaz et al., 1998; Webb et al., 2002; Schwilk and Ackerly, 2005; Pausas and Verdú, 2010). Regarding functional diversity, one way to do this is by comparing the distribution of functional traits of each community with that from a random assembly of species from the regional species pool. Communities with lower values of functional diversity than the null expectation (i.e., functional clustering) are, in general, thought to be shaped by environmental filtering that allows the occurrence of only a reduced range of traits (Zobel, 1997). On the other hand, communities with higher values of functional diversity than the null expectation (i.e., functional overdispersion) are shaped by limiting similarity processes, such as competition or facilitation, which select species presenting disparate functional traits (Weiher and Keddy, 1995). Again, lakes can be considered ideal models to study these facets of biodiversity as the delimitation of both local communities and regional species pools are facilitated. However, interpreting natural communities using this framework is not as straightforward as it may appear, particularly when incorporating the determinants of the phylogenetic structure of communities. Many concurrent evolutionary processes play a major role in determining the phylogenetic diversity of local communities. Due to this, processes that apparently would produce different communities, such as competition and environmental filtering, may produce similar phylogenetic (but not functional) structures (Losos, 2008; Mayfield and Levine, 2010; Hille Ris Lambers et al., 2012; Adler et al., 2013). Further, the spatial (and temporal) scale also plays a major role in the interpretation of community structure. While both convergence and divergence processes can shape functional diversity at the local scale, convergence typically predominates at larger scales, so regional assemblages tend towards trait redundancy (see De Bello et al., 2009). As a consequence, community structure cannot be understood only from the functional patterns described above. Rather, it needs to incorporate information on whether trait values are either conserved or convergent across the tips of the phylogeny (Pausas and Verdú, 2010; Pavoine and Bon- 
sall, 2011; Cadotte et al., 2013), bearing in mind the spatial scale of the analysis (De Bello et al., 2009; Hortal et al., 2012).

The study of functional and phylogenetic diversity has increased exponentially during the last decade (Cianciaruso, 2011). Despite following the same trend, still very few studies in lakes focus on these aspects of diversity when compared to other environments (Fig. 2). The few limnological studies analysing functional and phylogenetic diversity were performed over regional scales. In the particular case of functional diversity, community structure has been assessed through the use of functional groups (Reynolds et al., 2002), an approach that has been criticized for assuming too many arbitrary decisions and for perceiving species within groups as functionally redundant (Magurran, 2004; Petchey and Gaston, 2006; Carneiro et al., 2010). In fact, several groups working on stream ecosystems have used trait composition and functional diversity metrics rather than functional groups to study community structure (Statzner et al., 2004; Poff et al., 2006; Feld et al., 2013). Functional and phylogenetic diversity measure aspects of biodiversity that are not fully covered by species richness or evenness (see Longhi and Beisner, 2010; Litchman et al., 2010). Changes in functional (and phylogenetic) community structure can alter completely the functioning of lentic ecosystems (Matsuzaki et al., 2013). Knowledge on this research area is still scarce (Sternberg and Kennard, 2014; Vogt et al., 2013). Therefore, additional efforts can provide significant developments on the conceptual body of modern limnology.

\section{CONCLUSIONS}

We identify a set of typical macroecological questions that are particularly suited to the use of lakes as study systems, such as the determinants of species diversity and community variation, or the effects of body size on ecosystem functioning. However, the use of lakes for macroecological research presents several caveats that need to be accounted for, or assumed explicitly in the study design. Within-lake habitat diversity can be a confounding factor for studies on groups whose species use different parts of the lake ecosystem. This problem can be easily solved by studying different groups (note that most species are habitat specific), by conducting standardized surveys that account for habitat diversity, and either study each habitat separately, or include habitat diversity explicitly in the analyses. Further, local factors (e.g., physicochemical variables) are of extreme importance for the structure and diversity of lentic communities. Hence, good-quality data on the geomorphology and origin of lakes should be included in the studies of diversity gradients or species' trait variations, together with other - generally used - environmental variables such as climate. As the size of the lentic habitats determines the impact of diversity in ecosystem functioning (Korhonen et al., 2011), the study of their macroecological patterns should include data and samples from water bodies across the whole ecosystem size gradient.

Given the discrete and isolated nature of lakes and ponds, it is not surprising that most studies on metacommunity were developed in aquatic systems. Results from these studies are, from one side, already using important concepts and methods from macroecology and, from another side, contributing to the advancement of this field in general. This is perhaps the best indicator of the potential gains in wetting macroecology or spatializing limnology at broad scales. The relatively easy measurement of some ecosystem properties related with its functioning (e.g., biomass, eutrophication, productivity, etc.) allows studying the relationships between guild structure, species interactions and diversity and ecosystem functioning. We believe that lakes (and ponds) are particularly suited for the study of the most functional aspects of macroecology, because the different biotic and abiotic parts of the ecosystem can be examined, measured and controlled for relatively easily. This allows teasing apart many of the confounding factors that introduce noise in the outcomes of macroecological processes. Here it is necessary to take into account that many lakes have suffered the effects of climate change and substantial anthropogenic alterations such as eutrophication or the introduction of invasive species, which in most cases imply strong ecological changes. Therefore when using large lake datasets for macroecological studies it is also important to take into account these alterations, which in some particular cases might completely mask any global ecological pattern. Despite this unavoidable drawback (which is also common to most, if not all, ecosystems), lakes and ponds hold a great potential to foster the advance of macroecological theory, similarly to their prominent role in the origin of modern ecology.

\section{ACKNOWLEDGMENTS}

We thank Diego Fontaneto for his invitation to write this perspective, and to two anonymous referees for their constructive suggestions. JH is funded by a Spanish DGCyT Ramón y Cajal fellowship. JCN is supported by CNPq (563834/2010-2), FAPEG and CAPES (Auxpe 2036/2013), AMCS by a Portuguese Fundação para a Ciência e a Tecnologia grant (SFRH/BPD/70709/2010) and JC by Spanish Ministry of Education FPU fellowship (FPU12/00575). JH and AMCS obtained additional support from the CSIC-CNPq bilateral project 2011BR0071, and MV from the Spanish Government projects Fundalzoo (CGL2010-14841), Invasivefish (427/2011) and the Biodiversity Conservation Plan from ENDESA S.A. with the project number 6900014499. 


\section{REFERENCES}

Adler PBA, Fajardo A, Kleinhesselink AR, Kraft NJB, 2013. Trait-based tests of coexistence mechanisms. Ecol. Lett. 16:1294-1306.

Algarte V, Rodrigues L, Landeiro V, Siqueira T, Bini L, 2013. Variance partitioning of deconstructed periphyton communities: does the use of biological traits matter? Hydrobiologia:1-12.

Allen AP, Gillooly JF, 2006. Assessing latitudinal gradients in speciation rates and biodiversity at the global scale. Ecol. Lett. 9:947-54.

Amarasinghe US, Welcomme RL, 2002. An analysis of fish species richness in natural lakes. Environ. Biol. Fish. 65:327-339.

Anderson MJ, Crist TO, Chase JM, Vellend M, Inouye BD, Freestone AL, Sanders NJ, Cornell HV, Comita LS, Davies KF, Harrison SP, Kraft NJB, Stegen JC, Swenson NG, 2011. Navigating the multiple meanings of $\beta$ diversity: a roadmap for the practicing ecologist. Ecol. Lett. 14:19-28.

Balian EV, Segers H, Lévêque C, Martens K, 2008. An introduction to the Freshwater Animal Diversity Assessment (FADA) project. Hydrobiologia 595:3-8.

Bagella S, Gascón S, Caria MC, Sala J, Mariani MA, Boix D, 2010. Identifying key environmental factors related to plant and crustacean assemblages in Mediterranean temporary ponds. Biodiv. Conserv. 19:1749-1768.

Barbour CD, Brown JH, 1974. Fish species diversity in lakes. Am. Nat. 108: 473-489.

Barbour MT, Gerritsen J, Snyder BD, Stribling JB, 1999. Rapid bioassessment protocols for use in streams and wadeable rivers: periphyton, benthic macroinvertebrates and fish, 2nd ed. EPA 841-B-99-002. U.S. Environmental Protection Agency, Office of Water, Washington: $339 \mathrm{pp}$.

Beck J, Ballesteros-Mejia L, Buchmann CM, Dengler J, Fritz SA, Gruber B, Hof C, Jansen F, Knapp S, Kreft H, Schneider AK, Winter M, Dormann CF, 2012. What's on the horizon for macroecology? Ecography 35:673-683.

Beisner BE, Peres PR, Lindstrom ES, Barnett A, Longhi ML, 2006. The role of environmental and spatial processes in structuring lake communities from bacteria to fish. Ecology 87:2985-2991.

Biggs J, Williams P, Whitfield P, Nicole P, Weatherby A, 2005. 15 years of pond assessment in Britain: results and lessons learned from the work on pond conservation. Aquat. Conserv. 15:693-714.

Blanchet S, 2012. The use of molecular tools in invasion biology: an emphasis on freshwater ecosystems. Fisheries Manag. Ecol. 19:120-132.

Boukal DS, 2014. Trait- and size-based descriptions of trophic links in freshwater food webs: current status and perspectives. J. Limnol. 73(Suppl.1):171-185.

Bosiacka B, Pienkowski P, 2012. Do biogeographic parameters matter? Plant species richness and distribution of macrophytes in relation to area and isolation of ponds in NW Polish agricultural landscape. Hydrobiologia 689:79-90.

Braun A, 1855. [Algarum unicellularium genera novea vel minus cognita]. [Book in Latin]. W. Engelmann, Leipzig: $111 \mathrm{pp}$.

Brönmark C, 1985. Freshwater snail diversity: effects of pond area, habitat heterogeneity and isolation. Oecologia 67:127-131.
Brooks RT, Colburn EA, 2012. "Island" attributes and benthic macroinvertebrates of seasonal forest pools. Northeast. Nat. 19:559-578.

Brose U, Ostling A, Harrison K, Martinez ND, 2004. Unified spatial scaling of species and their trophic interactions. Nature 428:167-171.

Brown JH, Maurer BA, 1989. Macroecology - The division of food and space among species on continents. Science 243:1145-1150.

Browne RA, 1981. Lakes as islands: biogeographic distribution, turnover rates, and species composition in the lakes of Central New York. J. Biogeogr. 8:75-83.

Brucet S, Pédron S, Mehner T, Lauridsen TL, Argillier C, Winfield IJ, Volta P, Emmrich M, Hesthagen T, Holmgren K, Benejam L, Kelly F, Krause T, Palm A, Rask M, Jeppesen E, 2013. Fish diversity in European lakes: geographical factors dominate over anthropogenic pressures. Freshw. Biol. 58:1779-1793.

Cadotte M, Albert CH, Walker SC, 2013. The ecology of differences: Assessing community assembly with trait and evolutionary distances. Ecol. Lett. 16:1234-1244.

Carneiro FM, Bini LM, Rodrigues LC, 2010. Influence of taxonomic and numerical resolution on the analysis of temporal changes in phytoplankton communities. Ecol. Ind. 10:249-255.

Chase JM, 2007. Drought mediates the importance of stochastic community assembly. P. Natl. Acad. Sci. USA 104:1743017434.

Chase JM, 2010. Stochastic community assembly causes higher biodiversity in more productive environments. Science 328:1388-1391.

Chase JM, Leibold MA, 2003. Ecological niches. Linking classical and contemporary approaches. The University of Chicago Press, Chicago: 211 pp.

Chambers PA, Kalff J, 1985. Depth distribution and biomass of submersed aquatic macrophyte communities in relation to Secchi depth. Can. J. Fish. Aquat. Sci. 42:701-709.

Cianciaruso MV, 2011. Beyond taxonomical space: large-scale ecology meets functional and phylogenetic diversity. Frontiers Biogeogr. 3:87-90.

Collen B, Whitton F, Dyer EE, Baillie JEM, Cumberlidge N, Darwall WRT, Pollock C, Richman NI, Soulsby A-M, Böhm M, 2013. Global patterns of freshwater species diversity, threat and endemism. Global Ecol. Biogeogr. 23:40-51.

Colwell RK, Rangel TF, 2009. Hutchinson's duality: the once and future niche. P. Natl. Acad. Sci. USA 106:19651-19658.

Cottenie K, Michels E, Nuytten N, De Meester L, 2003. Zooplankton metacommunity structure: Regional $v s$. Local processes in highly interconnected ponds. Ecology 84:991-1000.

Cousyn C, De Meester L, Colbourne JK, Brendonck L, Verschuren D, Volckaert F, 2001. Rapid, local adaptation of zooplankton behavior to changes in predation pressure in the absence of neutral genetic changes. P. Natl. Acad. Sci. USA 98:6256-6260.

Cucherousset J, Olden JD, 2011. Ecological impacts of nonnative freshwater fishes. Fisheries 36:215-230.

Cucherousset J, Blanchet S, Olden JD, 2012. Non-native species promote trophic dispersion of food webs. Frontiers Ecol. Environ. 10:406-408.

De Bello F, Thuiller W, Lepš J, Choler P, Clément J-C, Macek P, Sebastià MT, Lavorel S, 2009. Partitioning of functional 
diversity reveals the scale and extent of trait convergence and divergence. J. Veg. Sci. 20:475-486.

De Bie T, De Meester L, Brendonck L, Martens K, Goddeeris B, Ercken D, Hampel H, Denys L, Vanhecke L, Van der Gucht K, Van Wichelen J, Vyverman W, Declerck SAJ, 2012. Body size and dispersal mode as key traits determining metacommunity structure of aquatic organisms. Ecol. Lett. 15:740-747.

De Meester L, Pantel JH, 2014. Eco-evolutionary dynamics in freshwater systems. J. Limnol. 73(Suppl.1):193-200.

De Meester L, Gómez A, Okamura B, Schwenk K, 2002. The Monopolization Hypothesis and the dispersal-gene flow paradox in aquatic organisms. Acta Oecol. 23:121-135.

Diamond JM, 1969. Avifaunal equilibria and species turnover rates on the Channel islands of California. P. Natl. Acad. Sci. USA 64:57-63.

Diamond JM, 1970. Ecological consequences of island colonization by southwest Pacific birds, 1. Types of niche shifts. P. Natl. Acad. Sci. USA 67:529-536.

Díaz S, Cabido M, Casanoves F, 1998. Plant functional traits and environmental filters at a regional scale. J. Veg. Sci. 9:113-122.

Dick JA, Alexander M, Jeschke J, Ricciardi A, MacIsaac H, Robinson T, Kumschick S, Weyl OF, Dunn A, Hatcher M, Paterson R, Farnsworth K, Richardson D, (2013). Advancing impact prediction and hypothesis testing in invasion ecology using a comparative functional response approach. Biol. Inv. (in press) doi: 10.1007/s10530-013-0550-8.

Diniz-Filho JAF, Gouveia SF, Lima-Ribeiro MS, 2013. Evolutionary macroecology. Front. Biogeogr. 5:195-203.

Diniz-Filho JAF, Rodríguez MÁ, Bini LM, Olalla-Tárraga MÁ, Cardillo M, Nabout JC, Hortal J, Hawkins BA, 2009. Climate history, human impacts and global body size of Carnivora (Mammalia: Eutheria) at multiple evolutionary scales. J. Biogeogr. 36:2222-2236.

Downing JA, 2010. Emerging global role of small lakes and ponds: little things mean a lot. Limnetica 29:9-24.

Duarte CM, Kalff J, Peters RH, 1986. Patterns in biomass and cover of aquatic macrophytes in lakes. Can. J. Fish. Aquat. Sci. 43:1900-1908.

Eadie JM, Hurly TA, Montgomerie RD, Teather KL, 1986. Lakes and rivers as islands: Species-area relationships in the fish faunas of Ontario. Environ. Biol. Fish. 15:81-89.

Ebert D, 1994. Virulence and local adaptation of a horizontally transmitted parasite. Science 265:1084-1086.

Elser JJ, Peace AL, Kyle M, Wojewodzic M, McCrackin ML, Andersen T, Hessen DO, 2010. Atmospheric nitrogen deposition is associated with elevated phosphorus limitation of lake zooplankton. Ecol. Lett. 13:1256-1261.

Emerson BC, 2002. Evolution on oceanic islands: molecular phylogenetic approaches to understanding pattern and process. Mol. Ecol. 11:951-966.

Faith DP, 1992. Conservation evaluation and phylogenetic diversity. Biol. Conserv. 61:1-10.

Fallu MA, Allaire N, Pienitz R, 2002. Distribution of freshwater diatoms in 64 Labrador (Canada) lakes: species-environment relationships along latitudinal gradients and reconstruction models for water colour and alkalinity. Can. J. Fish. Aquat. Sci. 59:329-349.

Feld CK, de Bello F, Dolédec S, (2013). Biodiversity of traits and species both show weak responses to hydromorphological alteration in lowland river macroinvertebrates. Freshw. Biol. (in press) doi:10.1111/fwb.12260.

Fenchel T, Finlay BJ, 2004. The ubiquity of small species: Patterns of local and global diversity. Bioscience 54:777-784.

Feroz Khan M, Panikkar P, 2009. Assessment of impacts of invasive fishes on the food web structure and ecosystem properties of a tropical reservoir in India. Ecol. Model. 220:2281-2290.

Finlay BJ, Esteban GF, 2007. Body size and bogeography, p. 167-185. In: A.G. Hildrew, D.G. Raffaelli and R. EdmondsBrown (eds.), Body size: the structure and function of aquatic ecosystems. Cambridge University Press, New York.

Finlay BJ, Esteban GF, Fenchel T, 1996. Global diversity and body size. Nature 383:132-133.

Fontaneto D, Brodie J, 2011. Why biogeography of organisms?, p. 3-10. In: D. Fontaneto (ed.), Biogeography of micro-organisms. Is everything small everywhere? Cambridge University Press, Cambridge.

Fontaneto D, Hortal J, 2012. Microbial biogeography: is everything small everywhere?, p. 87-98. In: L.A. Ogilvie and P.R. Hirsch (eds.), Microbial ecological theory: current perspectives. Caister Academic Press, Norfolk.

Fontaneto D, Hortal J, 2013. At least some protist species are not ubiquitous. Mol. Ecol. 22:5053-5055.

Forbes SA, 1887. The lake as a microcosm. Bulletin of the Peoria Scientific Association, pp. 77-87.

Gesierich D, Rott E, 2012. Is diatom richness responding to catchment glaciation? A case study from Canadian headwater streams. J. Limnol. 71:72-83.

Gillespie RG, Roderick GK, 2002. Arthropods on islands: colonization, speciation, and conservation. Annu. Rev. Entomol. 47:595-632.

Gillooly JF, Dodson SI, 2000. Latitudinal patterns in the size distribution and seasonal dynamics of new world, freshwater cladocerans. Limnol. Oceanogr. 45:22-30.

González-Bergonzoni I, Meerhoff M, Davidson T, Teixeira-de Mello F, Baattrup-Pedersen A, Jeppesen E, 2012. Metaanalysis shows a consistent and strong latitudinal pattern in fish omnivory across ecosystems. Ecosystems 15:492-503.

Gouveia SF, Hortal J, Cassemiro FAS, Rangel TF, Diniz-Filho JAF, 2013. Nonstationary effects of productivity, seasonality, and historical climate changes on global amphibian diversity. Ecography 36:104-113.

Gouveia SF, Hortal J, Tejedo M, Duarte H, Cassemiro FAS, Navas CA, Diniz-Filho JAF, (2014). Climatic niche at physiological and macroecological scales: thermal tolerance-geographic range interface and niche dimensionality. Global Ecol. Biogeogr. (in press) doi:10.1111/geb.12114.

Gravel D, Poisot T, Desjardins-Proulx P, 2014. Using neutral theory to reveal the contribution of meta-community processes to assembly in complex landscapes. J. Limnol. 73(Suppl.1):61-73.

Grenyer R, Orme CDL, Jackson SF, Thomas GH, Davies RG, Davies TJ, Jones KE, Olson VA, Ridgely RS, Rasmussen PC, Ding T-S, Bennett PM, Blackburn TM, Gaston KJ, Gittleman JL, Owens IPF, 2006. Global distribution and conservation of rare and threatened vertebrates. Nature 444:93-96.

Griffiths D, 2006. Pattern and process in the ecological biogeography of European freshwater fish. J. Anim. Ecol. 75:734-751.

Griffiths D, McGonigle C, Quinn R, 2014. Climate and species 
richness patterns of freshwater fish in North America and Europe. J. Biogeogr. 41:452-463.

Grönroos M, Heino J, Siqueira T, Landeiro VL, Kotanen J, Bini LM, 2013. Metacommunity structuring in stream networks: roles of dispersal mode, distance type, and regional environmental context. Ecol. Evol. 3:4473-4487.

Guisan A, Rahbek C, 2011. SESAM - a new framework integrating macroecological and species distribution models for predicting spatio-temporal patterns of species assemblages. J. Biogeogr. 38:1433-1444.

Hairston NG, Walton WE, 1986. Rapid evolution of a life-history trait. P. Natl. Acad. Sci. USA 83:4831-4833.

Håkanson L, Peters RH, 1995. Predictive limnology: methods for predictive modelling. SPB Academic Publ., Amsterdam: 464 pp.

Hallstan S, Trigal C, Johansson KL, Johnson R, (2013). The impact of climate on the geographical distribution of phytoplankton species in boreal lakes. Oecologia 173:16251638 .

Harris AT, Woolnough DA, Zanatta DT, 2011. Insular lake island biogeography: using lake metrics to predict diversity in littoral zone mollusk communities. J. N. Am. Benthol. Soc. 30:997-1008.

Hawkins BA, 2001. Ecology's oldest pattern? Trends Ecol Evol $16: 470$

Hawkins BA, 2008. Recent progress toward understanding the global diversity gradient. IBS Newsletter 6:5-8.

Hawkins BA, Diniz-Filho JAF, 2008. Macroecology. Encyclopedia of Life Sciences (eLS). J. Wiley \& Sons Ltd., Chichester. doi:10.1002/9780470015902.a0003273.pub2.

Hawkins BA, Diniz-Filho JAF, Jaramillo CA, Soeller SA, 2007. Climate, niche conservatism, and the global bird diversity gradient. Am. Nat. 170:S16-S27.

Heino J, 2011. A macroecological perspective of diversity patterns in the freshwater realm. Freshwater Biol. 56:1703-1722.

Heino J, 2013. The importance of metacommunity ecology for environmental assessment research in the freshwater realm. Biol. Rev. 88:166-178.

Heino J, Soininen J, 2010. Are common species sufficient in describing turnover in aquatic metacommunities along environmental and spatial gradients? Limnol. Oceanogr. 55:2397-2402.

Heino J, Grönroos M, Soininen J, Virtanen R, Muotka T, 2012. Context dependency and metacommunity structuring in boreal headwater streams. Oikos 121:537-544.

Heino J, Schmera D, Erős T, 2013. A macroecological perspective of trait patterns in stream communities. Freshw. Biol. 58:1539-1555.

Hessen DO, Faafeng BA, Smith VH, Bakkestuen V, Walseng B, 2006. Extrinsic and intrinsic controls of zooplankton diversity in lakes. Ecology 87:433-443.

Hillebrand H, 2004. On the generality of the latitudinal diversity gradient. Am. Nat. 163:192-211.

Hille Ris Lambers J, Adler PB, Harpole WS, Levine JM, Mayfield MM, 2012. Rethinking community assembly through the lens of coexistence theory. Annu. Rev. Ecol. Evol. S. 43:227-248.

Hockin DC, 1982. Experimental insular zoogeography: some tests of the equilibrium theory using meiobenthic harpacticoid copepods. J. Biogeogr. 9:487-497.
Hof C, Brandle M, Brandl R, 2008. Latitudinal variation of diversity in European freshwater animals is not concordant across habitat types. Global Ecol. Biogeogr. 17:539-546.

Hooper DU, Chapin III FS, Ewel JJ, Hector A, Inchausti P, Lavorel S, Lawton JH, Lodge DM, Loreau M, Naeem S, Schmid B, Setälä H, Symstad AJ, Vandermeer J, Wardle DA, 2005. Effects of biodiversity on ecosystem functioning: a consensus of current knowledge. Ecol. Mon. 75:3-35.

Hortal J, 2011. Geographical variation in the diversity of microbial communities: research directions and prospects for experimental biogeography, p. 335-356. In: D. Fontaneto (ed.), Biogeography of micro-organisms. Is everything small everywhere? Cambridge University Press, Cambridge.

Hortal J, De Marco P Jr., Santos AMC, Diniz-Filho JAF, 2012. Integrating biogeographical processes and local community assembly. J. Biogeogr. 39:627-628.

Hortal J, Diniz-Filho JAF, Bini LM, Rodríguez MÁ, Baselga A, Nogués-Bravo D, Rangel TF, Hawkins BA, Lobo JM, 2011. Ice age climate, evolutionary constraints and diversity patterns of European dung beetles. Ecol. Lett. 14:741-748.

Hortal J, Lobo JM, Jiménez-Valverde A, 2007. Limitations of biodiversity databases: case study on seed-plant diversity in Tenerife (Canary Islands). Conserv. Biol. 21:853-863.

Hortal J, Roura-Pascual N, Sanders NJ, Rahbek C, 2010. Understanding (insect) species distributions across spatial scales. Ecography 33:51-53.

Hortal J, Triantis KA, Meiri S, Thébault E, Sfenthourakis S, 2009. Island species richness increases with habitat diversity. Am. Nat. 173:E205-E217.

Hulme PE, Nentwig W, Pyšek P, Vilá MA, 2009. DAISIE, Handbook of alien species in Europe. Springer, Dordrecht: 382 pp.

Hubbard M, 1973. Experimental insular biogeography: ponds as islands. Florida Scient 36:132-141.

Hutchinson GE, 1957. A treatise on limnology, vol. 1. J. Wiley \& Sons, New York: 1015 pp.

Hutchinson GE, 1978. An introduction to population biology. Yale University Press, New Haven.

Irz P, Argillier C, Oberdorff T, 2004. Native and introduced fish species richness in French lakes: local and regional influences. Global Ecol. Biogeogr. 13:335-344.

Jackson MC, Allen R, Pegg J, Britton JR, 2013. Do trophic subsidies affect the outcome of introductions of a non-native freshwater fish? Freshwater Biol. 58:2144-2153.

Jenkins DG, 2014. Lakes and rivers as microcosms, version 2.0. J. Limnol. 73(Suppl.1):20-32.

Jenkins DG, Buikema AL Jr., 1998. Do similar communities develop in similar sites? A test with zooplankton structure and function. Ecol. Mon. 68:421-443.

Jones JI, Jeppensen E, 2007. Body size and trophic cascades in lakes, p. 118-139. In: A.G. Hildrew, D.G. Raffaelli and R. Edmonds-Brown (eds.), Body size: the structure and function of aquatic ecosystems, Cambridge University Press, New York.

Jonsson T, Cohen JE, Carpenter SR, 2005. Food webs, body size, and species abundance in ecological community description. Adv. Ecol. Res. 36:1-84.

Keddy PA, 1976. Lakes as islands: the distributional ecology of two aquatic plants, Lemna Minor L. and L. Trisulca L. Ecology 57:353-359.

Knapp RA, Matthews KR, Sarnelle O, 2001. Resistance and re- 
silience of alpine lake fauna to fish introductions. Ecol. Mon. 71:401-421.

Korhonen JJ, Wang J, Soininen J, 2011. Productivity-diversity relationships in lake plankton communities. PLoS ONE 6:e22041.

Kouki J, Niemela P, Viitasaari M, 1994. Reversed latitudinal gradient in species richness of sawflies (Hymenoptera, Symphyta). Ann. Zool. Fenn. 31:83-88.

Lampert W, Sommer U, 2007. Limnoecology. Oxford University Press, New York: 324 pp.

Lappalainen J, Soininen J, 2006. Latitudinal gradients in niche breadth and position-regional patterns in freshwater fish. Naturwissenschaften 93:246-250.

Leibold MA, Norberg J, 2004. Biodiversity in metacommunities: Plankton as complex adaptive systems? Limnol. Oceanogr. 49:1278-1289.

Leibold MA, Holyoak M, Mouquet N, Amarasekare P, Chase JM, Hoopes MF, Holt RD, Shurin JB, Law R, Tilman D, Loreau M, Gonzalez A, 2004. The metacommunity concept: a framework for multi-scale community ecology. Ecol. Lett. 7:601-613.

Lévêque C, Oberdorff T, Paugy D, Stiassny MLJ, Tedesco PA, 2008. Global diversity of fish (Pisces) in freshwater. Hydrobiologia 595:545-567.

Lewis WM Jr., 1996. Tropical lakes: how latitude makes a difference, p. 43-64. In: F. Schiemer and K.T. Boland (eds.), Perspectives in tropical limnology. SPB Academic Publishing bv, Amsterdam.

Lewis WM Jr., 2000. Basis for the protection and management of tropical lakes. Lakes \& Reservoirs: Research and Management 5:35-48.

Litchman E, de Tezanos Pinto P, Klausmeier C, Thomas M, Yoshiyama K, 2010. Linking traits to species diversity and community structure in phytoplankton. Hydrobiologia 653:15-28.

Logue JB, Mouquet N, Peter H, Hillebrand H, 2011. Empirical approaches to metacommunities: a review and comparison with theory. Trends Ecol. Evol. 26:482-491.

Longhi ML, Beisner BE, 2010. Patterns in taxonomic and functional diversity of lake phytoplankton. Freshwater Biol. 55:1349-1366.

Losos JB, 2008. Phylogenetic niche conservatism, phylogenetic signal and the relationship between phylogenetic relatedness and ecological similarity among species. Ecol. Lett. 11:995-1003.

Losos JB, Ricklefs RE, 2009. Adaptation and diversification on islands. Nature 457:830-836.

MacArthur RH, Wilson EO, 1963. An equilibrium theory of insular zoogeography. Evolution 17:373-387.

MacArthur RH, Wilson EO, 1967. The theory of island biogeography. Princeton University Press, Princeton: 224 pp.

MacArthur RH, Diamond JM, Karr JR, 1972. Density compensation in island faunas. Ecology 53:330-342.

Magurran AE, 2004. Measuring biological diversity. Blackwell, Oxford: $256 \mathrm{pp}$.

Maly EJ, Maly MP, 1974. Dietary differences between two cooccurring calanoid copepod species. Oecologia 17:325-333.

March F, Bass D, 1995. Application of Island Biogeography theory to temporary pools. J. Freshwater Ecol. 10:83-85.

Margalef R, 1983. Limnología. Omega, Barcelona: 1010 pp.
Margalef R, 1984. Ecología. Omega, Barcelona: 951 pp.

Margules CR, Pressey RL, 2000. Systematic conservation planning. Nature 405:243-253.

Martiny JBH, Bohannan BJM, Brown JH, Colwell RK, Fuhrman JA, Green JL, Horner-Devine MC, Kane M, Krumins JA, Kuske CR, Morin PJ, Naeem S, Ovreas L, Reysenbach A-L, Smith VH, Staley JT, 2006. Microbial biogeography: putting microorganisms on the map. Nat. Rev. Microbiol. 4:102-112.

Matsuzaki SS, Sasaki T, Akasaka M, 2013. Consequences of the introduction of exotic and translocated species and future extirpations on the functional diversity of freshwater fish assemblages. Global Ecol. Biogeogr. 22:1071-1082.

Matuszek JE, Beggs GL, 1988. Fish species richness in relation to lake area, $\mathrm{pH}$, and other abiotic factors in Ontario Lakes. Can. J. Fish. Aquat. Sci. 45:1931-1941.

Mayfield MM, Levine JM, 2010. Opposing effects of competitive exclusion on the phylogenetic structure of communities: phylogeny and coexistence. Ecol. Lett. 13:1085-1093.

Mehner T, Holmgren K, Lauridsen TL, Jeppesen E, Diekmann M, 2007. Lake depth and geographical position modify lake fish assemblages of the European 'Central Plains' ecoregion. Freshw. Biol. 52:2285-2297.

Messier J, McGill BJ, Lechowicz MJ, 2010. How do traits vary across ecological scales? A case for trait-based ecology. Ecol. Lett. 13:838-848.

Minns CK, 1989. Factors affecting fish species richness in Ontario lakes. T. Am. Fish. Soc. 118:533-545.

Mittelbach GG, Schemske DW, Cornell HV, Allen AP, Brown JM, Bush MB, Harrison SP, Hurlbert AH, Knowlton N, Lessios HA, McCain CM, McCune AR, McDade LA, McPeek MA, Near TJ, Price TD, Ricklefs RE, Roy K, Sax DF, Schluter D, Sobel JM, Turelli M, 2007. Evolution and the latitudinal diversity gradient: speciation, extinction and biogeography. Ecol. Lett. 10:315-331.

Mori T, Murakami M, Saitoh T, 2010. Latitudinal gradients in stream invertebrate assemblages at a regional scale on Hokkaido Island, Japan. Freshw. Biol. 55:1520-1532.

Muylaert K, Pérez-Martínez C, Sánchez-Castillo P, Lauridsen T, Vanderstukken M, Declerck SJ, Gucht K, Conde-Porcuna J-M, Jeppesen E, Meester L, Vyverman W, 2010. Influence of nutrients, submerged macrophytes and zooplankton grazing on phytoplankton biomass and diversity along a latitudinal gradient in Europe. Hydrobiologia 653:79-90.

Nabout JC, Carneiro FM, Borges PP, Machado KB, Huszar VLM, (2013). Brazilian scientific production on phytoplankton studies: national determinants and international comparisons. Braz. J. Biol. (in press).

Nabout JC, Siqueira T, Bini LM, Nogueira IdS, 2009. No evidence for environmental and spatial processes in structuring phytoplankton communities. Acta Oecol. 35:720-726.

Nekola JC, White PS, 1999. The distance decay of similarity in biogeography and ecology. J. Biogeogr. 26:867-878.

Nel JL, Roux DJ, Abell R, Ashton PJ, Cowling RM, Higgins JV, Thieme M, Viers JH, 2009. Progress and challenges in freshwater conservation planning. Aquat. Conserv. 19:474-485.

Nilsson E, Solomon CT, Wilson KA, Willis TV, Larget B, Vander Zanden MJ, 2012. Effects of an invasive crayfish on trophic relationships in north-temperate lake food webs. Freshwater Biol. 57:10-23. 
Odum EP, 1963. Primary and secundary energy flow in relation to ecosystem structure. Proc. XVI Int. Congr. Zool. 4:336-338.

Ohlberger J, Mehner T, Staaks G, Hölker F, 2008. Temperaturerelated physiological adaptations promote ecological divergence in a sympatric species pair of temperate freshwater fish, Coregonus spp. Funct. Ecol. 22:501-508.

Olalla-Tárraga MÁ, McInnes L, Bini LM, Diniz-Filho JAF, Fritz SA, Hawkins BA, Hortal J, Orme CDL, Rahbek C, Rodríguez MÁ, Purvis A, 2011. Climatic niche conservatism and the evolutionary dynamics in species range boundaries: global congruence across mammals and amphibians. J. Biogeogr. 38:2237-2247.

Olden JD, Kennard MJ, Leprieur F, Tedesco PA, Winemiller KO, García-Berthou E, 2010. Conservation biogeography of freshwater fishes: recent progress and future challenges. Divers. Distr. 16:496-513.

Paavola R, Muotka T, Virtanen R, Heino J, Jackson D, MakiPetays A, 2006. Spatial scale affects community concordance among fishes, benthic macroinvertebrates, and bryophytes in streams. Ecol. Appl. 16:368-379.

Pausas JG, Verdú M, 2010. The jungle of methods for evaluating phenotypic and phylogenetic structure of communities. Bioscience 60:614-625.

Pavoine S, Bonsall MB, 2011. Measuring biodiversity to explain community assembly: a unified approach. Biol. Rev. 86:792-812.

Petchey OL, Gaston KJ, 2006. Functional diversity: back to basics and looking forward. Ecol. Lett. 9:741-758.

Peters RH, 1986. The role of prediction in limnology. Limnol. Oceanogr. 31:1143-1159.

Pinel-Alloul B, André A, Legendre P, Cardille JA, Patalas K, Salki A, 2013. Large-scale geographic patterns of diversity and community structure of pelagic crustacean zooplankton in Canadian lakes. Global Ecol. Biogeogr. 22:784-795.

Poff NL, Olden JD, Vieira NKM, Finn DS, Simmons MP, Kondratieff BC, 2006. Functional trait niches of North American lotic insects: traits-based ecological applications in light of phylogenetic relationships. J. N. Am. Benthol. Soc. 25:730-755.

Poquet JM, Mesquita-Joanes F, 2011. Combined effects of local environment and continental biogeography on the distribution of Ostracoda. Freshwater Biol. 56:448-469.

Rabenold KN, 1979. A reversed latitudinal diversity gradient in avian communities of Eastern deciduous forests. Am. Nat. 114:275-286.

Rajaniemi TK, Goldberg DE, Turkington R, Dyer AR, 2006. Quantitative partitioning of regional and local processes shaping regional diversity patterns. Ecol. Lett. 9:121-128.

Reynolds C, Huszar V, Kruk C, Naselli-Flores L, Melo S, 2002. Towards a functional classification of the freshwater phytoplankton. J. Plankton Res. 24:417-428.

Richter-Boix A, Teplitsky C, Rogell B, Laurila A, 2010. Local selection modifies phenotypic divergence among Rana temporaria populations in the presence of gene flow. Mol. Ecol. 19:716-731.

Ricklefs RE, 2008. Disintegration of the ecological community. Am. Nat. 172:741-750.

Ricklefs R, Bermingham E, 2008. The West Indies as a laboratory of biogeography and evolution. Phil. T. R. Soc. B 363:2393-2413.
Rolon AS, Lacerda T, Maltchik L, Guadagnin DL, 2008. Influence of area, habitat and water chemistry on richness and composition of macrophyte assemblages in southern Brazilian wetlands. J. Veg. Sci. 19:221-228.

Rosenfield JA, 2002. Pattern and process in the geographical ranges of freshwater fishes. Global Ecol. Biogeogr. 11: 323-332.

Rørslett B, 1991. Principal determinants of aquatic macrophyte richness in northern European lakes. Aquat. Bot. 39:173-193.

Santos AMC, Quicke DLJ, 2011. Large-scale diversity patterns of parasitoid insects. Entomol. Sci. 14:371-382.

Santos AMC, Quicke DLJ, Borges PAV, Hortal J, 2011. Species pool structure determines the level of generalism of island parasitoid faunas. J. Biogeogr. 38:1657-1667.

Scherber C, Eisenhauer N, Weisser WW, Schmid B, Voigt W, Fischer M, Schulze E-D, Roscher C, Weigelt A, Allan E, Beszler H, Bonkowski M, Buchmann N, Buscot F, Clement LW, Ebeling A, Engels C, Halle S, Kertscher I, Klein A-M, Koller R, Konig S, Kowalski E, Kummer V, Kuu A, Lange M, Lauterbach D, Middelhoff C, Migunova VD, Milcu A, Muller R, Partsch S, Petermann JS, Renker C, Rottstock T, Sabais A, Scheu S, Schumacher J, Temperton VM, Tscharntke T, 2010. Bottom-up effects of plant diversity on multitrophic interactions in a biodiversity experiment. Nature 468:553-556.

Schwilk DW, Ackerly DD, 2005. Limiting similarity and functional diversity along environmental gradients. Ecol. Lett. $8: 272-281$.

Soberón J, 2007. Grinnellian and Eltonian niches and geographic distributions of species. Ecol. Lett. 10:1115-1123.

Soininen J, 2012. Macroecology of unicellular organisms - patterns and processes. Environ. Microbiol. Rep. 4:10-22.

Soininen J, Korhonen JJ, Karhu J, Vetterli S, 2011. Disentangling the spatial patterns in community composition of prokaryotic and eukaryotic lake plankton. Limnol. Oceanogr. 56:508-520.

Statzner B, Dolédec S, Hugueny B, 2004. Biological trait composition of European stream invertebrate communities: assessing the effects of various trait filter types. Ecography 27:470-488.

Stendera S, Adrian R, Bonada N, Cañedo-Argüelles M, Hugueny B, Januschke K, Pletterbauer F, Hering D, 2012. Drivers and stressors of freshwater biodiversity patterns across different ecosystems and scales: a review. Hydrobiologia 696:1-28.

Sternberg D, Kennard MJ, 2014. Phylogenetic effects on functional traits and life history strategies of Australian freshwater fish. Ecography 37:54-64.

Stomp M, Huisman J, Mittelbach GG, Litchman E, Klausmeier CA, 2011. Large-scale biodiversity patterns in freshwater phytoplankton. Ecology 92:2096-2107.

Straile D, Jochimsen MC, Kümmerlin R, 2013. The use of longterm monitoring data for studies of planktonic diversity: a cautionary tale from two Swiss lakes. Freshwater Biol. 58:1292-1301.

Strock K, Saros J, Simon K, McGowan S, Kinnison M, 2013. Cascading effects of generalist fish introduction in oligotrophic lakes. Hydrobiologia 711:99-113.

Svenning JC, Skov F, 2007. Could the tree diversity pattern in Europe be generated by postglacial dispersal limitation? Ecol. Lett. 10:453-460. 
Tilman D, 2001. Functional diversity, p. 109-120. In: S.A. Levin (ed.), Encyclopedia of biodiversity. Academic Press, San Diego.

Tisseuil C, Cornu JF, Beauchard O, Brosse S, Darwall W, Holland R, Hugueny B, Tedesco PA, Oberdorff T, 2013. Global diversity patterns and cross-taxa convergence in freshwater systems. J. Anim. Ecol. 82:365-376.

Vamosi SM, 2014. Phylogenetic community ecology as an approach for studying old ideas on competition in the plankton: opportunities and challenges. J. Limnol. 73(Suppl.1):186-192.

Van der Gucht K, Cottenie K, Muylaert K, Vloemans N, Cousin S, Declerck S, Jeppesen E, Conde-Porcuna JM, Schwenk K, Zwart G, Degans H, Vyverman W, De Meester L, 2007. The power of species sorting: local factors drive bacterial community composition over a wide range of spatial scales. P. Natl. Acad. Sci. USA 104:20404-20409.

Van Doorslaer W, Vanoverbeke J, Duvivier C, Rousseaux S, Jansen M, Jansen B, Feuchtmayr H, Atkinson D, moss B,Stocks R, De Meester L, 2009. Local adaptation to higher temperatures reduces immigration success of genotypes from a warmer region in the water flea Daphnia. Global Chang. Biol. 15:3046-3055.

Verleyen E, Vyverman W, Sterken M, Hodgson DA, Wever AD, Juggins S, Vijver BVd, Jones VJ, Vanormelingen P, Roberts D, Flower R, Kilroy C, Souffreau C, Sabbe K, 2009. The importance of dispersal related and local factors in shaping the taxonomic structure of diatom metacommunities. Oikos 118:1239-1249.

Vogt RJ, Peres-Neto PR, Beisner BE, 2013. Using functional traits to investigate the determinants of crustacean zooplankton community structure. Oikos 122:1700-1709.

Vyverman W, Verleyen E, Sabbe K, Vanhoutte K, Sterken M, Hodgson DA, Mann DG, Juggins S, Vijver BVd, Jones V, Flower R, Roberts D, Chepurnov VA, Kilroy C, Vanormelingen $\mathrm{P}$, Wever AD, 2007. Historical processes constrain patterns in global diatom diversity. Ecology 88:1924-1931.

Violle C, Navas ML, Vile D, Kazakou E, Fortunel C, Hummel I, Garnier E, 2007. Let the concept of trait be functional! Oikos 116:882-892.

Vitule JRS, Freire CA, Simberloff D, 2009. Introduction of non-native freshwater fish can certainly be bad. Fish Fish. 10:98-108.

Wahl D, Wolfe M, Santucci V Jr., Freedman J, 2011. Invasive carp and prey community composition disrupt trophic cascades in eutrophic ponds. Hydrobiologia 678:49-63.

Warren P, 1996. The effects of between-habitat dispersal rate on protist communities and metacommunities in microcosms at two spatial scales. Oecologia 105:132-140.

Webb CO, 2000. Exploring the phylogenetic structure of ecological communities: an example for rain forest trees. Am. Nat. 156:145-155.

Webb CO, Ackerly DD, McPeek MA, Donoghue MJ, 2002. Phylogenies and community ecology. Annu. Rev. Ecol. Evol. S. 33:475-505.

Weiher E, Keddy PA, 1995. Assembly rules, null models, and trait dispersion: new questions from old patterns. Oikos 74:159-164.

Wetzel RG, 2001. Limnology: Lake and river ecosystems, 3rd ed. Academic Press, San Diego: 1009 pp.

Wetzel CE, Bicudo DdC, Ector L, Lobo EA, Soininen J, Landeiro VL, Bini LM, 2012. Distance decay of similarity in Neotropical diatom communities. PLoS ONE 7:e45071.

Weyhenmeyer GA, Peters H, Willén E, 2013. Shifts in phytoplankton species richness and biomass along a latitudinal gradient - consequences for relationships between biodiversity and ecosystem functioning. Freshwater Biol. 58:612-623.

Whittaker RJ, Araújo MB, Jepson P, Ladle RJ, Watson JEM, Willis KJ, 2005. Conservation biogeography: assessment and prospect. Divers. Distr. 11:3-23. Whittaker RJ, Fernández-Palacios JM, 2007. Island biogeography: ecology, evolution, and conservation. Oxford University Press: 416 pp.

Whittaker RJ, Triantis KA, Ladle RJ, 2008. A general dynamic theory of oceanic island biogeography. J. Biogeogr. 35: 977-994.

Wiens JJ, Donoghue MJ, 2004. Historical biogeography, ecology and species richness. Trends Ecol. Evol. 19:639-644.

Willig MR, Kaufman DM, Stevens RD, 2003. Latitudinal gradients of biodiversity: pattern, process, scale, and synthesis. Annu. Rev. Ecol. Evol. S. 34:273-309.

Yvon-Durocher G, Montoya JM, Trimmer M, Woodward GUY, 2011. Warming alters the size spectrum and shifts the distribution of biomass in freshwater ecosystems. Global Change Biol. 17:1681-1694.

Zobel M, 1997. The relative role of species pools in determining plant species richness. An alternative explanation of species coexistence? Trends Ecol. Evol. 12:266-269. 